\title{
TTR
}

Traduction, terminologie, rédaction

\section{Ana Pano Alamán and Fabio Regattin. Tradurre un classico della scienza. Traduzioni e ritraduzioni dell'Origin of Species di Charles Darwin in Francia, Italia e Spagna [Translating a classic science text. Translations and retranslations of On the Origin of Species by Charles Darwin in France, Italy and Spain]. Bologna, Bononia University Press, 2015, 376 p.}

\section{Marco A. Fiola}

Volume 29, numéro 2, 2e semestre 2016

URI : https://id.erudit.org/iderudit/1051020ar

DOI : https://doi.org/10.7202/1051020ar

Aller au sommaire du numéro

\section{Éditeur(s)}

Association canadienne de traductologie

ISSN

0835-8443 (imprimé)

1708-2188 (numérique)

Découvrir la revue

Citer ce compte rendu

Fiola, M. A. (2016). Compte rendu de [Ana Pano Alamán and Fabio Regattin. Tradurre un classico della scienza. Traduzioni e ritraduzioni dell'Origin of Species di Charles Darwin in Francia, Italia e Spagna [Translating a classic science text. Translations and retranslations of On the Origin of Species by Charles Darwin in France, Italy and Spain]. Bologna, Bononia University Press, 2015, 376 p.] TTR, 29(2), 200-203. https://doi.org/10.7202/1051020ar d'utilisation que vous pouvez consulter en ligne. 
la variété des approches critiques et des textes étudiés, le collectif offre une contribution importante à la recherche sur les aspects historiques de la traduction, et sur son rôle séminal, non seulement dans la formation des langues et littératures nationales, dont les enjeux à la Renaissance sont bien connus, mais aussi dans la création d'un espace transnational où circulent les idées, les livres, et les agents humains dont dépend la dissémination des textes de part et d'autre de la Manche.

\section{Références}

Bassnett, Susan et André Lefevere (1998). Constructing Cultures. Essays on Literaty Translation. Londres, Multilingual Matters.

Burke, Peter (2007). «Cultures of Translation in Early Modern Europe». In P. Burke et R.P. Hisa, dir. Cultural Translation in Early Modern Europe. Cambridge, Cambridge University Press, p. 7-38.

Boutcher, Warren (2016). «Intertraffic: Transnational Literatures and Languages in Late Renaissance England and Europe». In M. McLean et S. Barker, dir. International Exchange in the Early Modern Book World. Leiden/Boston, Brill, p. 343-374.

Coldiron, Anne E. B. (2015). Printers Without Borders. Translation and Textuality in the Renaissance. Cambridge, Cambridge University Press.

Hosington, Brenda M. (2013). Renaissance Cultural Crossroads. An Annotated and Analytical Catalogue of Translations, 1473-1640. Disponible à : <www.hrionline.ac.uk/rcc> [consulté le 15 févr. 2017]. Rhodes, Neil et al., dir. (2013). English Renaissance Translation Theory. Londres, Modern Humanities Research Association.

Marie-Alice Belle Université De MontréAL

Ana Pano Alamán and Fabio Regattin. Tradurre un classico della scienza. Traduzioni e ritraduzioni dell'Origin of Species di Charles Darwin in Francia, Italia e Spagna [Translating a classic science text. Translations and retranslations of On the Origin of Species by Charles Darwin in France, Italy and Spain]. Bologna, Bononia University Press, 2015, 376 p.

Translating scientific texts can be a daunting task; translating one that is considered by many to be the foundation of evolutionary biology requires fortitude, temerity, or vocation, if not, ideally, all three. Charles Darwin's On the Origin of Species is one such 
scientific text that has had an immeasurable scientific as well as philosophical, political and theological impact on society and on the way we think of nature, including ourselves as humans.

A failed medical and theology student, Darwin embarked in 1831 on the Beagle for a five-year voyage that was to take him along the South American coast, where he collected evidence that was to form the basis of his theory on the evolution of species. His findings would eventually send shockwaves around the world, thanks in no small part to translators who made the work accessible across language and geographic barriers. What remained relatively obscure until recently was the extent to which the transformation process that is translation impacted on the content and the wide-spread dissemination of Darwin's unique and revolutionary scientific text.

Not surprisingly, some of the early followers of Darwin's work were not to be found in his native Great Britain, but in continental Europe. Although it is into German then Dutch that On the Origin of the Species was first translated, Ana Pano Alamán and Fabio Regattin's book focuses on its translation into French, Italian and Spanish. The title of the book is somewhat misleading, since the authors are offering a study that goes far beyond the usual comparative analysis of an original text and its successive revised and augmented editions versus its translation(s). Tradurre is, in fact, a remarkably extensive study presenting a detailed history of On the Origin of Species, buttressed by an in-depth analysis of how the original was received then translated within each sociocultural context, how the translations were received by their respective readerships, how accurately the translations and re-translations conveyed the original, or how they influenced translations in other languages or were influenced by them. The authors succeed in providing, for the first time, a broad overview that takes into consideration not only textual aspects, but also the material conditions of publication, in addition to the translators and other agents involved in making the work available on an international scale. In doing so, the authors are required to describe, of course, but also to compare, oppose and assimilate national practices in order to make observations on local contexts in an attempt to highlight common and distinct practices. This is certainly the most original contribution of the book, and there are many others. 
Tradurre un classico della scienza is divided into four chapters. Following the first one-the "translation archeology" (a concept they are borrowing from Pym's methodology (1998, p. 5)), the authors offer an impressive bibliography detailing some 100 entries, including the successive original editions as well as their translations into French, Italian and Spanish, which the authors call "le tre principali lingue romanze" [the three main Romance languages]. This statement is somewhat puzzling since it is left unclear if they mean that they decided to focus on the three main Romance languages in Europe, or if those are the three main Romance languages into which On the Origin of Species was translated. Either way, Portuguese is not included in this study, even though it is the first language of over 200 million people and certainly an important language in its own right.

The order in which each target language is studied follows the order in which Darwin's book was introduced to the nonEnglish speaking world. The first part focuses on French, the second on Italian, and the third on Spanish. It must be noted that the authors explain how the work was first introduced to each language community, then translated. Sometimes, as in the case of parts of Italy and Spain, Darwin's work was read first in French, not in the original English, as evidenced in some Italian and Spanish translations.

In the introduction, the authors make reference to the works of Henri Meschonnic and Antoine Berman, for whom translation and re-translation are different phenomena, a reference which foreshadows what slowly unfolds in the book: successive Italian and Spanish translators used the first translation, Clémence Royer's French version, as their source text. A scholar in her own right, Royer was much less ambivalent than Darwin in her assertions (Brisset, 2002). She published her first translation of On the Origin of the Species in 1862, three years after the original English edition was published, and this French translation was instrumental in making Darwin more widely known across Europe, in spite of, or perhaps thanks to, Royer's more categorical approach to the subject. Questions of authorship, faithfulness to the readership, and the role of the translator are acutely posed in Tradurre un classico della scienza.

Alamán and Regattin offer readers a fascinating look into the dissemination of a monument of scientific literature across a single 
continent. The book is of interest not only because it provides insights into one of the most interesting works of literature of the $19^{\text {th }}$ century, but also because students and academics alike will find in it the results of a systematic and thorough research project covering the life of a masterpiece over one and a half centuries, across four languages and several countries.

\section{References}

Brisset, Annie (2002). "Clémence Royer ou Darwin en colère." In J. Delisle, ed. Portraits de traductrices. Ottawa, University of Ottawa Press, pp. 173-203.

Pym, Anthony (1998). Method in Translation History. Manchester, St. Jerome.

\section{Marco A. Fiola RYERSON UNIVERSITY}

\section{James W. Underhill. Voice and Versification in Translating Poems. Ottawa, University of Ottawa Press, coll. Perspectives on Translation, 2016, 333 p.}

Louvrage Voice and Versification in Translating Poems se veut une réponse à l'idée convenue que la traduction de la poésie est une tâche impossible. Faisant valoir que cette intraduisibilité supposée découle d'une division erronée entre le fond et la forme en poésie (à savoir que cette division n'a pas lieu d'être), James W. Underhill aborde la question en trois temps, d'abord en déconstruisant la conception classique de la forme en poésie dans la partie "Versification", puis en la reconstruisant en tandem avec le fond dans la partie "Form and Meaning in Poetry Translation» et enfin en utilisant l'approche de traduction qu'il préconise pour commenter des traductions de Baudelaire et de Dickinson dans la dernière partie, «Case Studies».

\section{Versification}

Dans la première partie, la plus volumineuse et la plus théorique du livre, Underhill fait valoir que la forme ne doit plus être considérée comme un aspect secondaire de la poésie ou, inversement, comme la seule caractéristique de ce genre littéraire. S'appuyant sur les travaux d'Henri Meschonnic, il montre comment la voix poétique jaillit de l'alliance entre le sens et la forme. C'est-à-dire que la forme n'est ni une béquille sur laquelle s'appuie le sens ni un cadre 